AT - TADBIR

JURNAL ILMIAH MANAJEMEN

Homepage: ojs.uniska.ac.id/attadbir

\title{
Halal Friendly Attribute Of Muslim Travelers Toward A Non-Muslim Destination
}

\author{
Ghea Putri Aliffia*, Rita Komaladewi \\ Fakultas Ekonomi, Universitas Padjadjaran \\ Jl. Dipati Ukur No. 35 Bandung 40132 \\ e-mail: gheaaliffia@gmail.com
}

\begin{abstract}
Halal tourism is a new phenomenon of the growth of the halal industry. The demand for halal products and services has also increased, both in tourist destinations obtained by having Muslim and non-Muslim populations. Muslim tourists have unique needs when traveling, especially if there is a tourist destination with a large population of non-Muslims. This study aims to determine the preferences of Muslim travelers through the analysis of halal friendly attributes on non-Muslim travel destinations. The sampling technique uses unknown population with a total sample of 100 respondents and the sampling technique uses purposive sampling (domestic travelers and a Muslim who have visited Bali tourism destination at least one time). The results of this study indicate that Muslim travelers preference based on halal friendly attributes in non-Muslim travel destinations of the most dominant attributes considered important are good of quality halal food and drinks as well as the availability of information about halal in the travel area. These attributes can be the main focus of attention for tourism service providers in order to improve the quality of Muslim-friendly tourism in Bali.
\end{abstract}

Keywords: preferences, halal tourism, muslim travelers, non-muslim travel destinations.

\begin{abstract}
Abstrak
Wisata halal merupakan fenomena baru dari pertumbuhan industri halal. Permintaan akan produk dan layanan halal pun semakin bertambah, baik pada tujuan wisata yang mayoritas memiliki penduduk yang beragama muslim maupun non-muslim. Wisatawan muslim memiliki kebutuhan yang khas dalam berwisata, terlebih jika berada pada tujuan wisata dengan sebagian besar penduduk nya merupakan non-muslim. Penelitian ini bertujuan untuk mengetahui preferensi wisatawan muslim melalui analisis halal friendly attribute pada tujuan wisata non-muslim. Teknik penentuan sampel menggunakan unknown population dengan jumlah sampel sebanyak 100 responden dan teknik pengambilan sampel menggunakan purposive sampling (wisatawan nusantara dan seorang muslim yang minimal satu kali pernah mengunjungi tempat wisata yang berada di Pulau Bali). Hasil dari penelitian ini menunjukkan bahwa preferensi wisatawan muslim berdasarkan halal friendly attribute di tujuan wisata non-muslim dari atribut yang paling dominan dianggap penting adalah makanan dan minuman halal yang berkualitas baik serta ketersediaan informasi mengenai kehalalan di area wisata. Atribut tersebut dapat menjadi fokus perhatian yang utama bagi penyedia layanan wisata agar dapat meningkatkan kualitas wisata ramah muslim yang ada di Pulau Bali.
\end{abstract}

Kata kunci: preferensi, wisata halal, wisatawan muslim, tujuan wisata non-muslim 


\section{INTRODUCTION}

As one of the world's largest economic sectors, travel \& tourism can create jobs, promote exports, and generate prosperity (World Travel \& Tourism Council, 2018). As explained by the former Minister of Tourism of the Republic of Indonesia Arief Yahya who said it is predicted that in another five years the tourism sector will be a core economy that can donate Indonesia's largest foreign exchange, with a projected value of 20 billion US dollars. If supported infrastructure is continuously upgraded most likely Indonesia's tourism sector become a new mainstay for the country's income (Abidin, 2019). In line with it, Rencana Pembangunan Jangka Menengah Nasional (RPJMN) 2015-2019 has made acceleration of tourism growth as one of the strategies of accelerated national economic growth. The government made a plan for tourism development program conducted with various strategies such as tourism promotion development, development with various tourism marketing partners, tourist market development, and the development of tourism imagery. All these strategies are done so that tourism growth goals are achieved. The goal of tourism development is increasing local business in tourism business and the number of local workers certified. In addition to the special interest tour (wisata minat khusus) namely Halal tourism is a strategic target in 2020-2024.

Halal tourism is one of the new phenomena emerging from the growth of the halal industry. When Halalmatters also things considered in the tourism industry, many Muslim and non-Muslim countries are working on the Muslim tourist market by providing tourism products, facilities and infrastructure to meet their needs (Samori, Md Salleh, \& Khalid, 2016). The size and scale of Muslim Travel markets are documented by a number of impressive statistics. It is estimated that the number of Muslims will increase to 2.8 billion or $30 \%$ of the world population in 2050. The admission of Muslim tourists amounted to 140 billion US dollars (11.6\% from global markets) in 2013. It surpassed the United States and China markets, which resulted in 131.3 billion U.S. dollars and 121.8 billion U.S. dollars in the same year. It was projected that Muslim tourists would reach 150 million and spend about 238 billion US dollars in 2020 (Crescentrating \& Mastercard, 2015).

Wishnutama as Minister of Tourism and Creative Economy (MENPAREKRAF) of the Republic of Indonesia said that he, along with the team of the Ministry of Tourism and Creative Economy, will make the tourist areas that residents of the population are not Muslims as Muslim-friendly tourist destinations such as Toba and Bali. Bali Island is still the most popular destination for Middle Eastern tourists visiting Indonesia. "After Bali, other popular destinations include Jakarta, Bandung and Bogor in West Java and, last Lombok," head of travel department and Tourism Promotion for Europe, Middle East, USA and Africa, Rita Sofia, as quoted by news agency Antara in Manama, Bahrain (TheJakartaPost, 2017). Muslim friendly beach facilities are popular with tourists coming from Middle East and North Africa (MENA), especially top tourist, in addition to tours such as cultural \& historical, religion site and shopping arcade. Based on the report data of the Global Islamic Economy Summit, the halal travelling spending was recorded turn over USD184 billion in 2017, especially from the countries of the Gulf Cooperation Council (GCC) which is relatively small, but has an average of spending to USD 5,000 per visit (sindonews.com, 2019).

The positive trend is also shown by the arrival of the archipelago tourists who enter 
the island of Bali. Domestic economy that grows about $5 \%$ accompanied by increasing purchasing power of society supporting increasing number of travel and shopping of domestic tourists (Kusnandar, 2019b). Tourists who visit the tourism in the island of Bali come from a variety of classes, groups, tribes, races, and different religions, so that the way to serve tourists and to fulfill the wants and needs of tourists will vary. One group of tourists who have special criteria in fulfilling the needs during the holidays is Muslim tourists. For example, both foreign and domestic Muslim travelers always choose halal food for their consumption as instructed by Allah SWT in holy Quran through QS. Al-Maidah Verse 88 which reads "and eat kosher food again from the things which God has given you, and give to God whom you have faith in him". In 2020 it is predicted that Indonesian Muslims will increase to 263.92 million and increase to 256.82 million in 2050. Thus, the Muslim population of Indonesia is $86.39 \%$ of the total population (Kusnandar, 2019a).

\section{LITERATURE REVIEW}

\section{Halal Friendly Atrribute}

Despite the scant knowledge of halalfriendly tourism characteristics in academic literature, there are a few studies that have defined the conceptual meaning of halal tourism (Han, Al-Ansi, Olya, \& Kim, 2019). Halal-friendly itself refers to the fulfillment of needs with the requirements or considerations for a Muslim (CrescentRating, 2016). The term 'Muslim-friendly' in tourism industry denotes an attempt to make the tourism experience enjoyable to observant Muslims (Battour, 2018). Religion has influenced the daily activities of Muslims, whether at home or daily life also in the context of traveling, thus Muslims made the choice of various tourist destinations whether the tourism destination has been suited to their needs as a Muslim (Jafari \& Scott, 2014). In non-Muslim countries, the special requirements are Muslims in terms of food and drink, daily worship, and travel patterns. Require certain adjustments in tourism offerings for most destinations in non-Muslim countries (Jafari \& Scott, 2014).

Muslim traveller behaviour is more complex, which is caused by attachment to the Shari'a of religion. Uncertainty that leads to unexpected behavioral responses from Muslim consumers (Olya \& Al-ansi, 2018). So, it takes research on complex interactions among Muslim Friendly Attribute to see the behavior of Muslim travelers visiting countries that are not predominantly Muslim or destinations that are not specifically intended for Muslim travelers (Han et al., 2019). According Heesup Han, Al-Ansi, Hossein G.T. Olya and Wansoo Kim in 2019, Halal Friendly Attribute itself consists of five dimensions, namely Halal Friendly Social Environment, Halal friendly Facilities, Halal Friendly Services, Halal Food and Beverages, Halal Friendly Locals and Staff (Han et al., 2019).

In the study investigating the relationship between the Islamic Attributes of Destination (IAD) to the satisfaction of Muslim tourists. It was discovered that "Islamic morality" was found to be the most important Islamic attribute, indicating that travel agents can choose hotels for Muslims, which are located far away from districts that are not in accordance with the sharia of Islam. Additional implications related to ' halal ', which is found to be the second most important Islamic attribute, can help marketers to satisfy Muslim travelers (Mohamed Battour, 2013).

This object of study is the island of Bali where in the previous study located in South Korea and then the age of the respondents 
who are more specific that is among the generation Z (born 1995 - 2015).

\section{METHODOLOGY}

Research Type

The research method used in this study is confirmatory. The main objective is to test whether the indicators that have been grouped based on their latent variables (the construction) are consistent in the construction or not. Descriptive analysis is used to examine which of the Halal Friendly Attribute variables are dominant as consumer preferences in non-Muslim tourist destinations on the island of Bali.

\section{Population and Sample}

The sampling technique to be used in this study is a non-probability sampling technique with purposive sampling. The research took research in Bandung City. The specific consideration or criteria in the sample in this research is Indonesian citizen, a Muslim who has at least once traveled on Bali Island. Based on the criteria that researchers have mentioned earlier, it is not known exactly the number of populations, therefore in this study to determine the large sample will use the unknown population formula. Based on the unknown population formula obtained as many as 100 people.

\section{Data Collection Techniques}

Data collection is carried out with two techniques namely field research and library research, primary data obtained through the dissemination of online questionnaire while secondary data used by library studies by studying scientific journals, and research has been conducted in advance to strengthen data about this research. While the field research, researchers will collect data using an online questionnaire through Google form which is done by distributing messages personally to respondents who meet the research criteria through whatssap and line personal message.

\section{RESULTS AND DISCUSSION}

Results

Sample collection was conducted in Bandung, with a total sample of 100 respondents. The sample comprised of $67 \%$ (67) females and 33\% (33) males. The age range of majority respondents is at the age range of 21-29 years or $89 \%$. The majority of the last education of respondents was high school graduates or $69 \%$. The occupation of respondents was dominated by students or $81 \%$. Average monthly earnings $<1.000 .000 .00$. Most of the Reponden answered recreation as the reason for visit to Bali Island is $86.1 \%$.

Based on the MSA (Measure of Sampling Adequacy) result, the whole indicator of Halal-Friendly Attribute can be analyzed further because each indicator has a value of more than 0.5 .

Table 3 shows there are 4 (four) factors formed, where the requirement to be a factor of the Eigenvalue should be $>1$. The Eigenvalue Component 1 is 7.492 or $>1$ and is able to describe $74.92 \%$ of variations. The Eigenvalue Component 2 is 1.861 or $>1$ and is able to describe $18.61 \%$ of variations. The Eigenvalue Component 3 is 1.378 or $>1$ and is able to describe $13.78 \%$ of the variation and Eigenvalue Component 4 value of 1.049 or $>1$ and is able to account for $10.49 \%$ of variations. Component values of 5 to 17 are not counted because the Eigenvalue $<1$ is not a factor. 
Table 1. Muslim traveller preferences toward halal freindly attribute

\begin{tabular}{|c|c|c|c|}
\hline No. & Indicators & Score & Description \\
\hline 1. & $\begin{array}{l}\text { The Halal-friendly social environment of tourist places is } \\
\text { comfort. }\end{array}$ & 4,38 & Important \\
\hline 2. & $\begin{array}{l}\text { The social environment of tourist places is free of haram items } \\
\text { (e.g. night clubs, red light districts). }\end{array}$ & 3,24 & $\begin{array}{l}\text { Moderately } \\
\text { Important }\end{array}$ \\
\hline 3. & $\begin{array}{l}\text { The social environment of tourist places is safe and clean for } \\
\text { Muslim travelers. }\end{array}$ & 4,27 & Important \\
\hline 4. & The atmospherics of tourist places comply with Islamic rules. & 3,52 & $\begin{array}{l}\text { Moderately } \\
\text { Important }\end{array}$ \\
\hline 5. & In general, it is convenient to access a mosque/prayer room. & 4,60 & Important \\
\hline 6. & Halal facilities are widely offered in tourist places/sites. & 4,27 & Important \\
\hline 7. & $\begin{array}{l}\text { Separate male and female Halal facilities are offered in tourist } \\
\text { sites (e.g. Spas, Swimming pools, Gyms). }\end{array}$ & 3,75 & $\begin{array}{l}\text { Moderately } \\
\text { Important }\end{array}$ \\
\hline 8. & $\begin{array}{l}\text { Separate prayer room facilities are offered to men/women in } \\
\text { tourist places. }\end{array}$ & 3,98 & $\begin{array}{l}\text { Moderately } \\
\text { Important }\end{array}$ \\
\hline 9. & Halal services offered in tourist places conform to Islamic law & 3,63 & $\begin{array}{l}\text { Moderately } \\
\text { Important }\end{array}$ \\
\hline 10. & Tourist information centers offer Halal service information & 4,42 & Important \\
\hline 11. & Availability of Halal food in tourist places. & 4,5 & Important \\
\hline 12. & $\begin{array}{l}\text { Halal food outlets/restaurants in tourist sites clearly display a } \\
\text { Halal logo. }\end{array}$ & 4,45 & Important \\
\hline 13. & $\begin{array}{l}\text { Halal food and beverage offered in tourist sites/places were } \\
\text { clean, safe, and hygienic. }\end{array}$ & 4,52 & Important \\
\hline 14. & $\begin{array}{l}\text { Halal food providers in tourist sites are accredited with Halal } \\
\text { certification. }\end{array}$ & 4,29 & Important \\
\hline 15. & $\begin{array}{l}\text { In tourist places, local staff is well aware of Halal products and } \\
\text { services. }\end{array}$ & 4,24 & Important \\
\hline 16. & Local staff understood how to offer Halal products and services. & 4,21 & Important \\
\hline 17. & $\begin{array}{l}\text { In general, locals had a good understanding of the Islamic and } \\
\text { Halal rules. }\end{array}$ & 4 & Important \\
\hline
\end{tabular}

Source: data processed, 2020

Table 2. Anti Image Matrice Halal-Friendly Attribute

\begin{tabular}{|c|c|c|c|c|c|c|c|c|c|c|c|c|c|c|c|c|c|}
\hline Construct & 1 & 2 & 3 & 4 & 5 & 6 & 7 & 8 & 9 & 10 & 11 & 12 & 13 & 14 & 15 & 16 & 17 \\
\hline 1 & 877 & & & & & & & & & & & & & & & & \\
\hline 2 & & .787 & & & & & & & & & & & & & & & \\
\hline 3 & & & .917 & & & & & & & & & & & & & & \\
\hline 4 & & & & 812 & & & & & & & & & & & & & \\
\hline 5 & & & & & .939 & & & & & & & & & & & & \\
\hline 6 & & & & & & .876 & & & & & & & & & & & \\
\hline 7 & & & & & & & 893 & & & & & & & & & & \\
\hline 8 & & & & & & & & 858 & & & & & & & & & \\
\hline 9 & & & & & & & & & 954 & & & & & & & & \\
\hline 10 & & & & & & & & & & .902 & & & & & & & \\
\hline 11 & & & & & & & & & & & .903 & & & & & & \\
\hline 12 & & & & & & & & & & & & .855 & & & & & \\
\hline 13 & & & & & & & & & & & & & 918 & & & & \\
\hline 14 & & & & & & & & & & & & & & .927 & & & \\
\hline 15 & & & & & & & & & & & & & & & .878 & & \\
\hline 16 & & & & & & & & & & & & & & & & .890 & \\
\hline 17 & & & & & & & & & & & & & & & & & .884 \\
\hline
\end{tabular}

Source: data processed, 2020 
Table 3. Total Variance Explained Halal-Friendly Attribute

\begin{tabular}{|c|r|r|r|r|r|r|r|r|r|}
\hline \multirow{2}{*}{ Construct } & \multicolumn{3}{|c|}{ Initial Eigenvalues } & \multicolumn{3}{|c|}{ Extraction Sums of Squared Loadings } & \multicolumn{2}{l|}{ Rotation Sums of Squared Loadings } \\
\cline { 2 - 11 } & Total & \% of Variance & Cumulative \% & Total & \% of Variance & Cumulative \% & Total & $\%$ of Variance & Cumulative \% \\
\hline 1 & 7.492 & 44.070 & 44.070 & 7.492 & 44.070 & 44.070 & 3.880 & 22.826 & 22.826 \\
\hline 2 & 1.861 & 10.950 & 55.020 & 1.861 & 10.950 & 55.020 & 2.945 & 17.324 & 40.150 \\
\hline 3 & 1.378 & 8.107 & 63.126 & 1.378 & 8.107 & 63.126 & 2.673 & 15.721 & 55.871 \\
\hline 4 & 1.049 & 6.173 & 69.299 & 1.049 & 6.173 & 69.299 & 2.283 & 13.428 & 69.299 \\
\hline 5 & .847 & 4.983 & 74.282 & & & & & & \\
\hline 6 & .677 & 3.983 & 78.265 & & & & & & \\
\hline 7 & .557 & 3.276 & 81.542 & & & & & & \\
\hline 8 & .499 & 2.936 & 84.478 & & & & & & \\
\hline 9 & .449 & 2.639 & 87.117 & & & & & & \\
\hline 10 & .382 & 2.246 & 89.363 & & & & & & \\
\hline 11 & .369 & 2.170 & 91.533 & & & & & & \\
\hline 12 & .325 & 1.911 & 93.444 & & & & & & \\
\hline 13 & .284 & 1.671 & 95.115 & & & & & & \\
\hline 14 & .264 & 1.555 & 96.670 & & & & & & \\
\hline 15 & .243 & 1.430 & 98.100 & & & & & & \\
\hline 16 & .179 & 1.054 & 99.154 & & & & & & \\
\hline 17 & .144 & .846 & 100.000 & & & & & & \\
\hline
\end{tabular}

Source: data processed, 2020

Table 4. Rotated Component Matrix Halal-Friendly Attribute

\begin{tabular}{|l|l|l|l|l|}
\hline \multirow{2}{*}{} & \multicolumn{4}{l}{ Construct } \\
\cline { 2 - 5 } & 1 & 2 & 3 & 4 \\
\hline SC_1 & .222 & .382 & .030 & .613 \\
SC_2 & .073 & .076 & .116 & .854 \\
SC_3 & .004 & .526 & .482 & .235 \\
SC_4 & .029 & .095 & .213 & .829 \\
F_1 & .500 & .639 & .145 & -.036 \\
F_2 & .423 & .593 & .014 & .240 \\
F_3 & .138 & .684 & .139 & .303 \\
F_4 & .111 & .736 & .202 & .058 \\
S_1 & .284 & .410 & .443 & .406 \\
S_2 & .672 & .481 & .152 & .099 \\
FNB_1 & .807 & .349 & .139 & .009 \\
FNB_2 & .728 & -.117 & .386 & .130 \\
FNB_3 & .825 & .208 & .158 & .143 \\
FNB_4 & .762 & .164 & .357 & .136 \\
LS_1 & .367 & .208 & .763 & .084 \\
LS_2 & .474 & .225 & .721 & .125 \\
LS_3 & .180 & .070 & .810 & .169 \\
\hline Source data processed, 2020
\end{tabular}

Source: data processed, 2020

Component Matrix is the result of the rotation process (rotated component matrix) indicates that the previous loading factor has a small value will be minimized and the loading factor that previously had a large value will be enlarged. Here is an explanation of the variables that will be entered into which factors:
The Halal-friendly social environment of tourist places is comfort (SC_1), the loading factor that has the greatest value is at a factor of 4 with a value of 0.613 . This shows that SC_ 1 are at factor 4 .

The social environment of tourist places is free of haram items (SC_2), the loading factor that has the greatest value is at a factor 
of 4 with a value of 0.854 . This shows that SC_ 2 are at factor 4 .

The social environment of tourist places is safe and clean for Muslim travelers (SC_3), The loading factor that has the greatest value is at a factor of 2 with a value of 0.526 . This shows that SC_3 are at factor 2 .

The atmospherics of tourist places comply with Islamic rules (SC_4), The loading factor that has the greatest value is at a factor of 4 with a value of 0.829 . This shows that $\mathrm{SC}_{-} 4$ are at factor 4.

In general, it is convenient to access a mosque/prayer room ( $\left.F_{-} 1\right)$, The loading factor that has the greatest value is at a factor of 2 with a value of 0.639 . This shows that F_1 are at factor 2 .

Halal facilities are widely offered in tourist places/sites (F_2), The loading factor that has the greatest value is at a factor of 2 with a value of 0.593 . This shows that $F \_2$ are at factor 2 .

Separate male and female Halal facilities are offered in tourist sites (F_3), The loading factor that has the greatest value is at the factor of 2 with a value of 0.684 . This shows that $F_{-} 3$ are at factor 2.

Separate prayer room facilities are offered to men/women in tourist places (F_4), The loading factor that has the greatest value is at a factor of 2 with a value of 0.736 . This shows that $\mathrm{F}_{-} 4$ are at factor 2 .

Halal services offered in tourist places conform to Islamic law (S_1), The loading factor which has the most value is at a factor of 3 with a value of 0.443 . This shows that S_1 are at factor 3 .

\section{Discussion}

Based on the research and the explanation that has been described earlier, the dominant preference from the viewpoint of Muslim tourists forms 4 (four) factors sorted from their importance. The first factor consists of Halal food and beverage offered in tourist sites/places were clean, safe, and hygienic have a value of 0,825 . Availability of Halal food in tourist places have a value of 0,807. Halal food providers in tourist sites are accredited with Halal certification have a value of 0,762 . Halal food outlets/restaurants in tourist sites clearly display a Halal logo have a value of 0,728 . Tourist information centers offer Halal service information have a value of 0,672 . The second factor consists of Separate prayer room facilities are offered to men/women in tourist places have a value of 0,736. Separate male and female Halal facilities are offered in tourist sites have a value of 0,684 . In general, it is convenient to access a mosque/prayer room have a value of 0,639 . Halal facilities are widely offered in tourist places/sites have a value of 0,593. The social environment of tourist places is safe and clean for Muslim travelers have a value of 0,526. The third factor consists of In general, locals had a good understanding of the Islamic and Halal rules have a value of 0,810 . In tourist places, local staff is well aware of Halal products and services have a value of 0,763. Local staff understood how to offer Halal products and services have a value of 0,721 . Halal services offered in tourist places conform to Islamic law have a value of 0,443 . The fourth factor consists of The social environment of tourist places is free of haram items have a value of 0,854 . The atmospherics of tourist places comply with Islamic rules have a value of 0,829 . The Halal-friendly social environment of tourist places is comfort have a value of 0,613 .

The result of the preference of Muslim travelers can be a reference for tour providers/marketers in evaluating and improving the facilities and services which are considered as dominant important in supporting the needs of Muslim travelers on non-Muslim tourism destinations It also can support the development of halal tourism in general. The indicators deemed important by 
the consumer are outlined in 5 (five) indicators. These indicators that should be the focus of attention in order to improve the quality of Muslim-friendly tourism on the island of Bali, but does not make other factors ruled out because it takes balance between all facilities and services to the performance of tourism especially halal tourism in the island of Bali can develop for the better. Based on the overall indicators considered important by Muslim tourists to indicate that Muslim tourists from Gen Z (born 1995 - 2015) put a top priority on halal food and beverages that are good quality and availability of Halal information on the tourist area. The points are supported from the dominant indicators. This is due to gene $\mathrm{Z}$ most likely not to apply Islamic Sharia consistently.

In the study of exploring halal-friendly destination attributes through perceptions and behaviors of Muslim travelers toward a non-Muslim destination in South Korea, according to NCA results muslim travelers choose the recommends halal food and beverage as a necessary condition for a halalfriendly destination (Han et al., 2019)

\section{CONCLUSIONS AND SUGGESTIONS}

\section{Conclusions}

Based on the research related to the analysis of Halal friendly attribute of Muslim tourists on non-Muslim tourism destinations, it can be concluded that from 17 (seventeen) Indicators of Halal friendly attribute are researched resulting in 5 (five) indicators that are considered dominant importance by Muslim tourists on non-Muslim tourism destinations. The indicator is (1) Halal food and beverage offered in tourist sites/places were clean, safe, and hygienic (2) Availability of Halal food in tourist places (3) Halal food providers in tourist sites are accredited with Halal certification (4) Halal food outlets/restaurants in tourist sites clearly display a Halal logo (5) Tourist information centers offer Halal service information. These points must be used as the main focus by tour providers/marketers to improve the quality of Muslim-friendly tourism destinations in Bali Island based on the preference of Muslim travelers on nonMuslim tourist destinations.

\section{Suggestion}

Based on the results of the study, here are suggestions for tour providers/marketers, dominant indicators come from the attributes of food and beverages. Therefore it is necessary for travel providers to have a good understanding of how to provide good quality halal food for Muslim travelers. Food and beverage providers are expected to meet the criteria as a provider of halal food such as safe, hygienic and healthy to consume also give halal signs/logos in the restaurant so that Muslim tourists do not hesitate to consume the product. Provide information centers about the halal in the tourist area. Muslim travelers often experience a lack of information about the halal when traveling to non-Muslim destination. Therefore, it is important for the tour provider to provide information center about the halal with the supply for local staffs about halal awareness. Along with the massive technological developments such as today a tour service provider can offer tips, recommendations, and itineraries to Muslim travelers through online platforms so it is easily accessible anytime and anywhere. Facility is the second order chosen by Muslim travelers, tour service providers are expected to provide or even improve the quality of their services by providing an easy to access, clean and comfortable and separate between male and female in tourist attractions such as shopping centers. For other facilities such as spa, swimming pool and fitness center are expected to apply similar that is a separate 
room among male visitors with female visitors to maintain privacy. The attributes of Locals and staff are in the third chosen by Muslim travellers, although the role of human resources becomes a front liner in terms of service delivery. To raise awareness of the halal service among employees, training needs to familiarize themselves with the basic requirements in terms of morality of Islam. For example, hotel staff, restaurant staff, tour guides, and travel agencies need to be equipped with an understanding of general halal services. For hotel staff, restaurant staff, tour guides and travel agencies also need to be attentive to Islamic attire and uniform behaviors (not using a mini-skirts, tights, nudy clothing). The limitations on this study are yet to explore the preference of Muslim tourists Nusantara as a whole, samples of Muslim tourists in Bandung have not been able to explain the population of Muslim tourists Nusantara. The research was limited by demographic only able to capture Muslim tourist preference derived from generation $\mathrm{Z}$ (born 1995-2015).

\section{REFERENCES}

Abidin, F. (2019). Pariwisata Sumbang Devisa Terbesar 5 Tahun Lagi, Ini Penjelasan Menpar. Retrieved September 13, 2019, from www.idxchannel.com website:

https://www.idxchannel.com/marketnews/pariwisata-sumbang-devisaterbesar-5-tahun-lagi-ini-penjelasanmenpar

Battour, M. (2018). Muslim Travel Behavior in Halal Tourism Muslim Travel Behavior in Halal Tourism. https://doi.org/10.5772/intechopen.7037 0

CrescentRating. (2016). Defining what is Halal Travel or Muslim Friendly Tourism. Retrieved September 23, 2019, from www.crescentrating.com website: https://www.crescentrating.com/magazin e/muslim-travel/3852/defining-what-ishalal-travel-or-muslim-friendlytourism.html

Crescentrating, \& Mastercard. (2015). Global Muslim Travel Index 2015. CrescentRating.

Han, H., Al-Ansi, A., Olya, H. G. T., \& Kim, W. (2019). Exploring halal-friendly destination attributes in South Korea: Perceptions and behaviors of Muslim travelers toward a non-Muslim destination. Tourism Management, 71(July 2018), 151-164. https://doi.org/10.1016/j.tourman.2018.1 0.010

Jafari, J., \& Scott, N. (2014). Annals of Tourism Research Muslim world and its tourisms. Annals of Tourism Research, 44 , $1-19$. https://doi.org/10.1016/j.annals.2013.08. 011

Kusnandar, V. B. (2019a). Berapa Jumlah Penduduk Muslim Indonesia? Retrieved from

https://databoks.katadata.co.id/datapubli sh/2019/09/24/berapa-jumlah-pendudukmuslim-indonesia

Kusnandar, V. B. (2019b). Jumlah Perjalanan Wisatawan Nusantara 2018 Tumbuh 12\%. Retrieved March 23, 2020, from https://databoks.katadata.co.id/datapubli sh/2019/07/03/jumlah-perjalananwisatawan-nusantara-2018-tumbuh-12

Mohamed Battour, M. B. and M. A. B. (2013). Islamic Attributes of Destination: Construct Development and Measurement Validation, and Their Impact on Tourist Satisfaction. International Journal of Tourism Research, (February 2013).

Olya, H. G. T., \& Al-ansi, A. (2018). Risk assessment of halal products and services: Implication for tourism industry. Tourism Management, 65, 279- 
291.

https://doi.org/10.1016/j.tourman.2017.1 0.015

Samori, Z., Md Salleh, N. Z., \& Khalid, M. M. (2016). Current trends on Halal tourism: Cases on selected Asian countries. Tourism Management Perspectives, 19, 131-136. https://doi.org/10.1016/j.tmp.2015.12.01 1

sindonews.com. (2019). Wisata Halal Engine of Wisata Indonesia 2019. Retrieved September 13, 2019, from www.nasional.sindonews.com website: https://nasional.sindonews.com/read/137 9967/18/wisata-halal-engine-of-wisataindonesia-2019-1550536201

TheJakartaPost. (2017). Bali Remains Most Popular Destination for Middle Eastern Tourists. Retrieved September 14, 2019, from www.thejakartapost.com website: https://www.thejakartapost.com/travel/2 017/12/18/bali-remains-most-populardestination-for-middle-easterntourists.html
World Travel \& Tourism Council. (2018). Travel \& Tourism Economic Impact 2018 World. In Travel and Tourism Impact 2018. https://doi.org/10.1093/elt/ccr029

Ringkasan Indeks. (n.d). Mei 12, 2019. https://www.idx.co.id/datapasar/ringkasan-perdagangan/ringkasanindeks/. (2006). Pasar Modal dan Manajemen Portofolio. Jakarta: Penerbit Erlangga.

Sekaran, U. (2017). Metode Penelitian Untuk Bisnis. Jakarta: Salemba Empat.

Tanderlilin, E. (2010). Portofolio dan Investasi Teori dan Aplikasi. Yogyakarta: Kanisius.

Wibowo, Agung (2017). Reaksi investor pasar modal Indonesia terhadap paket kebijakan ekonomi tahap I Jokowi-JK. Media Ekonomi dan Manajemen. 